\section{Britain losing out on its share of SDI research contracts}

\section{London}

BRITAIN's participation in the US Strategic Defense Initiative (SDI) research programme has failed to produce the hoped-for lucrative contracts, the House of Commons Defence Select Committee says in a recent report.

When a memorandum of understanding about British involvement in research and development for SDI was signed in December 1985, there were projections that UK companies would win $£ 1,500$ million in contracts. The report says, however, that by March this year only $\$ 34$ million (about $£ 20$ million) worth of orders and commissions had been awarded; that is expected to rise to $\$ 100$ million by the end of the year.

"SDI participation may not be the great bonanza that some thought", the Ministry of Defence admitted in evidence to the select committee. The $\$ 100$ million total is only 1.56 per cent of the total SDI budget for 1986 and 1987 . The committee notes that this is "disappointing".

More than 400 British companies have contacted the SDI Participation Office of the Ministry of Defence (MoD) expressing interest in the programme, but only 32 companies have so far been awarded contracts. About two-thirds of the funding so far is on a government-to-government basis, with most of this subcontracted to British industry, in accordance with Whitehall's aim of ensuring that not more than 15 per cent of the value of government-to-government contracts will be carried out in MoD research establishments.

The most valuable of these contracts in the "European Architecture Study", worth $\$ 9.9$ million, a "theoretical research study of the systems necessary for integrated defences of Europe within the context of a strategic defensive system for the defence of the continental USA and its allies against ballistic missiles".

Overall, the defence select committee concludes, "US funding of British SDI work has been directed much more at what former MoD chief scientific adviser Professor Sir Ronald Mason described as 'paper studies' such as the European Architecture Study, than at 'real system studies and innovative technological studies'. It must be a matter of doubt whether this situation will improve."

This predominance of "paper studies" militates against any appreciable levels of industrial spin-offs according to the report. Non-military spin-off would be much more likely to arise from more technological research, such as the European Eureka programme. Professor Mason told the committee: "If you have, say, in the Department of Trade and Industry, clear ideas as to what technologies need sponsorship, then to do it through the back door of SDI seems to be a cock-eyed way of going about it."

Other European countries have also signed intergovernmental agreements to participate in SDI research, but most have fared even worse than Britain. Only West Germany has done better, with a total of $\$ 42.5$ million in SDI contracts by April this year. Israel had contracts worth $\$ 10.8$ million francs, \$8.1 million; Italy, \$5.1 million; Belgium, $\$ 94,000 ;$ and the Netherlands, $\$ 43,000$.

The committee blames the poor performance of British and other non-US companies on "the intrinsic difficulties that face companies trying to penetrate the American defence market". As a major reason for continued involvement in SDI research, the committee cites the need to stay abreast of developments in strategic defence.

Kathy Johnston

\section{Government science budget criticized \\ London}

THE British government is failing to make available sufficient funds for scientific research and student support, a House of Commons all-party select committee has concluded. In a report published last week, the Education, Science and Arts Committee says that the existing volume of science research for 1987-88 and beyond "should at least be preserved".

Although expenditure on science is planned to increase in real terms from $£ 527$ million in $1986-87$ to $£ 558$ million in $1987-88$, there is a likelihood of real reductions in the following two years first to $£ 548$ million and then to $£ 542$ million. The committee dismissed government claims that the increased science budget in 1987-88 was serving to "maintain and enhance the strength and quality of the science base". It concludes that "the costs of science research will more than outweigh the extra resources. In short, the volume of science will be cut".

On student support, which is planned to decrease in real terms from $\$ 714$ million in $1987-88$ to $£ 705$ million in $1989-90$, while student numbers increase, the committee urges the government to "find the resources necessary to start a period of gradual real increases in the value of student awards".

The report expresses disquiet about the lack of information on financing, administration and accountability of the new City Technology Colleges (see Nature 327, 359; 1987).

Simon Hadlington
Hungary a focus for astrophysics?

\section{Balontfüred, Hungary}

Plans to develop Hungary as an international centre for astrophysics took a major step forward last week, says $\mathrm{Dr}$ Alexander Szalay of Budapest's Eötvös Lorand University. Szalay had just realized a long-standing dream - that of bringing leading astrophysicists of East and West together in Hungary - when his university co-hosted an International Astronomical Union (IAU) symposium on the structure of the Universe.

It is still rare for Soviet cosmologists to be able to travel to the West, so Hungary, with its liberal policy towards Western visitors, provides an ideal meeting place. At last week's symposium the Soviet Union sent a delegation of fifteen, about 10 per cent of all Soviet scholars specializing in cosmology, Szalay estimates. And as some members of the delegation were relatively young, there is perhaps a sign that the traditional Soviet approach to international trips is changing - previously only senior scientists have been allowed to travel, as a means of honouring them, but now, in astrophysics at least, it seems that travel may be seen as a normal part of a scientist's work.

Further evidence of a more liberal attitude in the Soviet Union is the recent visit of Dr Yakov Zel'dovich, doyen of Soviet cosmologists, to the United States. This was Zel'dovich's first US trip in decades. For many years Soviet astrophysicists have had to rely almost entirely on letters to maintain contact with US colleagues.

But even with Mr Mikail Gorbachev's new policy of glasnost - openness Szalay sees a role for Hungary in bringing East and West together. Government bureaucracies cannot change overnight, and it will still be easier for Soviet scientists to travel to Hungary than to the United States. Neither does Szalay see Hungary as merely a catalyst in the field of astrophysics. Hungarian astrophysicists believe that their contributions to the Vega probes of Venus and comet Halley fully justified their status as equal partners with the Soviet Union.

In keeping with his international outlook, Dr Szalay is also looking to the West for cooperative ventures. Negotiations are under way with the US National Science Foundation for a grant to finance exchange in theoretical astrophysics between Hungary and the United States. Szalay recognizes that the chances of EastWest cooperation are better in theoretical fields than in observational astrophysics, where sensitive 'state-of-the-art' technology such as computer-controlled detectors may be involved. Vera Rich 